\title{
区の境域とその中心の政治地理（1）
}

木 谷正夫

目次 (その内容)

1，「郡区町村編成法」以来の区

（まえがき）

2, 区に見る旧境界の積み重なりとその中心の移動………（東京の例を主として）

3，境界の近代化とその改編.

（大阪，名古屋の例を主として）

(以下次号)

4, 区の規模と区域.

（京都の例を主として）

5, 中心区の再編と周辺地域.

（神戸，横浜の例を主として）

6 , 区域の将来

（世界の大都市の例などから）

\section{1. 「郡区町村編成法」以来の区}

政治地理で扱う国境や首都の位置についての理論が，国内の地方区画や行政 区画，市町村役場などにそのまま応用できないてとはいうまでもない。まして 東京を沈じ，六大都市の区などについて，その境界や政治的中心ともいえる 区役所の位置を，それらと同類のものとして取上げるとと自体に，多くの疑点 があるであろう。

大都市の内部では，なんらかの意味においても境界を意識されるてとがまれ である。区境にか登らずいろいろの境界が大都市の内部を走っているとしても ぞれほどに日々の市民の活動を規制し，特色づけているととだろう。少なくと も外見上はいちじるしく注意をひく事項は乏しいようである。だからてそてれ まで地理学や地理教育上, 大都市の市域や外延について，それと行政地域との 関連などを取上げるととはあっても，大都市内部の行政的，政治的地域が問題 にされることはまれであった。

しかし，果しててれのみが正しい見方であろうか。外見上，注意をひくてと の少ないのはかならずしも実質的影響の乏しいととを意味しない。むしろその 逆のばあいが多い。境界をはじめ, 地名や地域の呼称など, 直接には視覚に訴 え，それから解決を迫ることの乏しい部門をおろそかにして来たのは，「景 観」論的な地理学や地理教育の犯したゆきすざではなかったらうか。最近, 番 地や町名の整理, 再編の問題が軒なみに起って来ているとと, 建築ブームや住 
宅難から大都市居住者に「土地」の登記や所属についての関心が高まって来て いるととについて, 地理としててれにどのように応光たらよいのか。また，年 少者にとっても「景観」に訴光る素材が提供されるよりさきに, 大都市と地方 との生活面拈ける交流がより緊密, 多岐にわたるようになって来た。てのば あいいまだ訪れたてとのない都市でも，まず関心をひく対象としてみじかにあ らわれるのは， $\times \times$ × $\triangle \triangle$ 町という方式で表わされる特定の場所についてでは なからうか。

古くから地理教育や地理研究上, 最良の友とされている地形図には, 境界や 地名なぞ現地では直接目に触れないものが記されている。地形図が明治初年以 来，一貫して一定の方針にしたがって正しく地名や境界を記録して来たてとは， 都市の境界を研究する上でも貴重な資料を残している。しかし，に゙っさいに 大都市でより多く利用されるいわゆる市街地四は, 町名, 番地がくいく記さ れ，かつそ机梳区境はもち万ん，町界が明嘹にひかれたるのである。区でと 待違った色で妨ったものや，区でとの区分地図のでときものが多く用いられて いる。てれらによってしぜんに区の位置や区域が解明に印象づけられていく結 果も無視できない。かつては町名や行政区画的なるののみを記した地図は地理 学徒住利用価值に之しいものと考光られていたとともある。市街地図の利用 がその基図である地形図を不要にしたり，その価值を下げたりしているわけで はないが，都市の理解と研究にいわゆる市街地図を使用しなければならなくな って来ている背景にはよく留意すべきであろう。

区や区域の理解が直接に景観から訴光られる面が少ないようにいったが, 最 近ではかならずしもてのようなととがいえなくなっている事実にいくどかめぐ

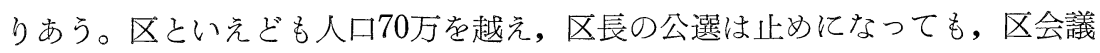
員を選び，区議会をもつてとから，区役所の建物の堂々としている点など，地 方の中心都市級以上の市役所の規模をもつものがつぎつぎとあらわれて来ても ふしぎではない。都市の再開発が叫ばれるとき, 人口は多くても狭い地域傹を 接する区が，古い伝統をたてにしたり，一方的な地域主義によって過度に自己 主張的になったりするのはその障害の大きなるのになるてともたしかである。 しかしいっぽう, 過大化す机ばするほどなんらかの方法による大都市地域の再 分割と内部的再編成が必要になる。明治11878年の郡区町村編成法以来の伝統をつ ぐ区が，種々の性格の変せん付耐学ながらも，なんらかの意味で，てれからも 東京をはじ她他の五大都市の再分割の基準になる適正規模をもつ単位として成 長するととが，やはりもっともしぜんで，円滑ななりゆきではないかと思われ 
る。

明治11年の「郡区町村編成法」によって生まれた区は「三府五港基地人民輻 湊ノ地八別ニ一区トナシ, 其広調ナル者八区分シテ数区トナス」1）という趣旨 そもとずき，まず東京の15区（名称は第 2 図参照）京都の 2 区（上，下）大阪 の4区（東, 西, 南, 北）と, おもな港や地方の有力都市がてれにあてられ た。2）明治22年市町村制の公布以後，市を細分した単位としての区は東京，大 阪，京都に限られることになったが，やがて人口 20 万以上の都市はてれをおく ことができるようになり，名古屋は明治41年，横浜は昭和 2 年，神戸は昭和 6 年から区制を実施した。区の性格や地位は, 当初からいくたびか变っている し, 都市でとに多少の違いもある。東京についていえば, 明治22年の市町村制 の公布のおり，一般市制とは異なり，特別市制として「東京市，京都市，大阪

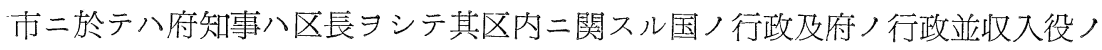
事務习補助執行セシムルコトヨ得3)」と定めた事項にしたがい, 明治31年の一 般市制に移るまで, 行政区的で, 市長や助役はいなくて, 区長のいる不完全な 公法人となった。その後, 明治44年の市制改正法律により, 区は課税権の主体 ではなく，また起債能力もないが，いちおう法人格を明定された自治区になっ た。

さらに昭和18年の都制と，昭和21年，昭和22年の地方自治法の改正により， 特別区としての性格をもち，自治区としての機能も高まった。昭和27年の改正 以後, 区は単に大都市の内部的構成団体としての地位にとどまり, 区長も区議 会で選出するが，都知事の承認を得て決まるととになっている。しかしてうし た区の機能の強弱，法的地位の変せんにかかわらず，区が大都市という地域を 細分するための最も単純でかつ法的に承認された単位としての性格を一貫して もちつづけて来たという事実にまず注目しなければならない。ての小論はとう した立場から区域や区の中心地域を取上げていくものである。

\section{2. 区に見る旧境界の積み重なりとその中心の移動}

区の境界や区の政治的中心である区役所の位置などを問題にするばあい，ま ずたいせつなととは，現沅にきびしすぎず，種々の不条理には寛大に高い立場 からその歴史的積み重なりに注目することである。土地所有関係の複雑さにも とずく市町村界の錯雑は，よほどの革命的事象が起らないかぎりたやすく消え 去ることが難しい。今日きわめて不合理に見える境界もかつての不合理の一部 をうけついで来ているし，一部で種々の実際生活上の必要から合理的な境界の 


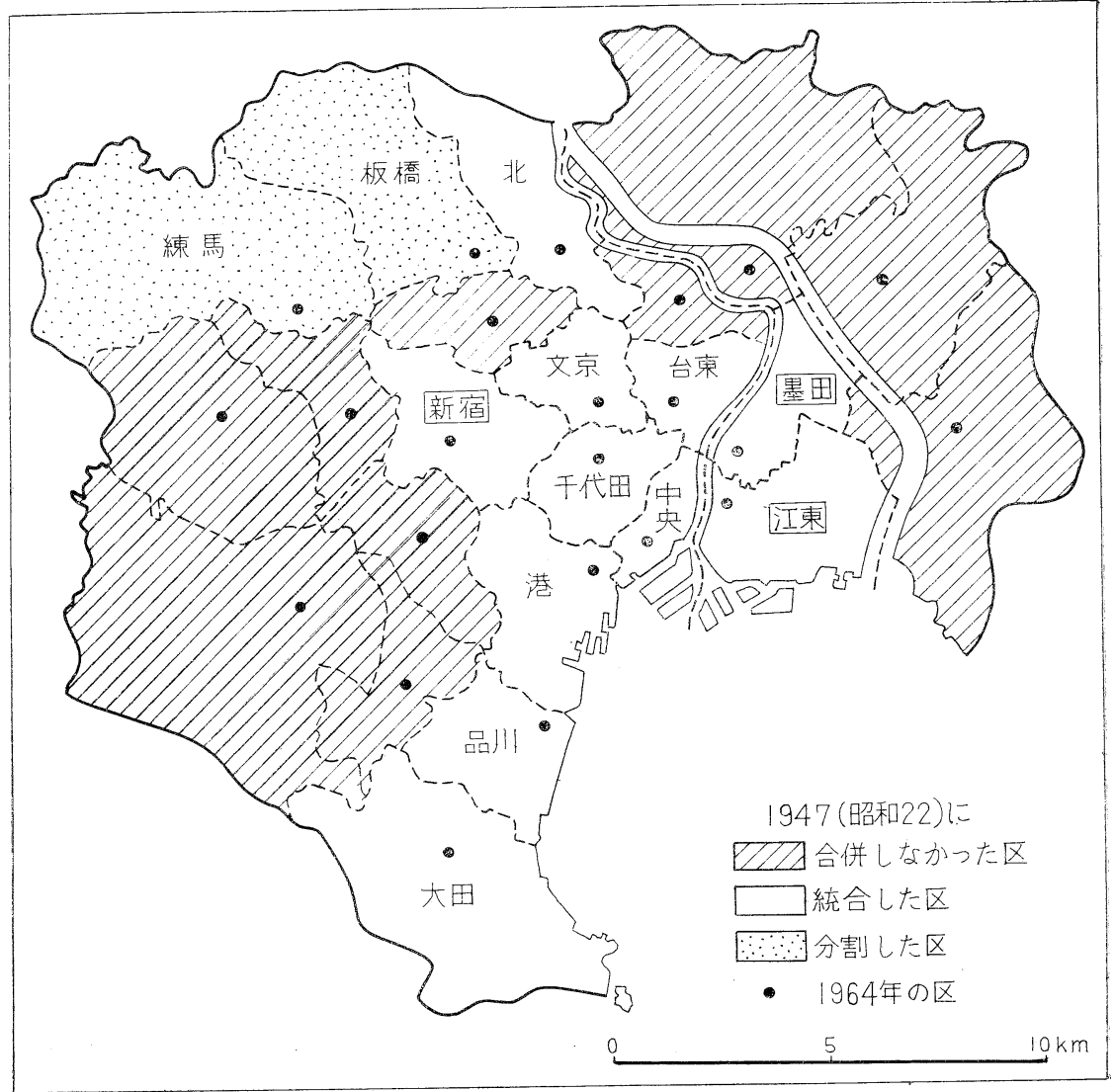

第1図 東京23区の構成（区名に—のあるのは旧市域〔15区〕と 新都市域〔1932年編入の市域〕にまたがって統合の行なわれたもの) 改定が行なおれても，どてかでいぜんとして古からの恣意的，独善的不条理の 部分が残されていくのがふつうである。境界とは本来てのように一気には不合 理が解決されず, 不条理とは見えても, その時々の実際生活上に起るいちじる しい不便や障害が関係者を積極的に動かさないが゙り，古いものがそのままう けつがれていくものである。問題は，長い期間に全体としてどのようにより合 理的なものに近づいて来ているかという点を検討することであろう。

東京都の区部といわれる23区の区域は, 第 1 図と第 2 図とで示すとおり, 昭 和22年に, これまでの35区のいくつかを 2 つないし 3 つずつ統合して $22 区 と$ 


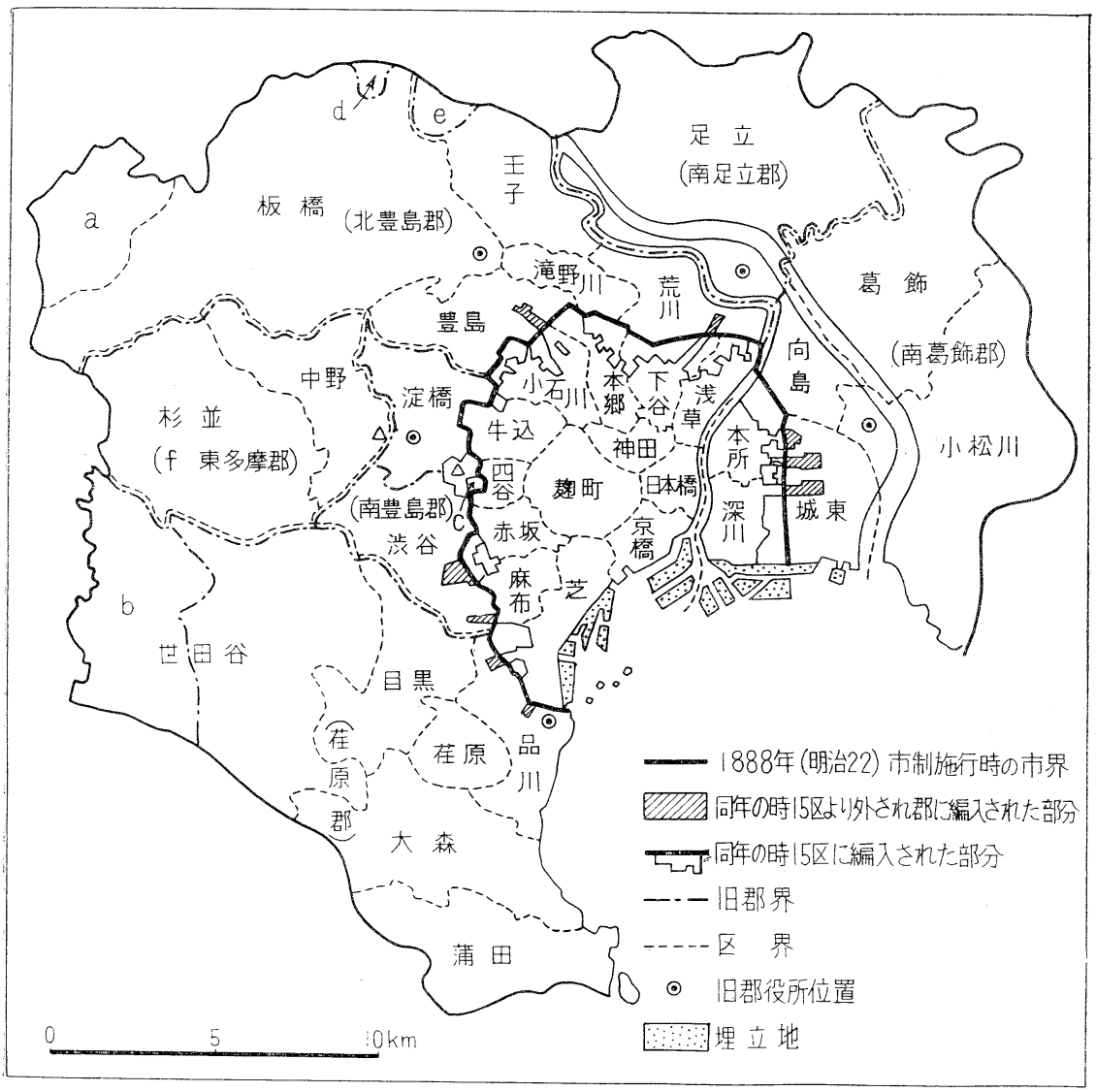

第 2 図 1947年（昭和22）までの東京旧35区の構成

a.1891年（明治24）石神井村上土支田と埼玉県新座郡搏橋村を合併して北壹 島郡に編入した旧大泉村 b. 1936年（昭和11）編入の旧千歳・砧村で，1893 年（明治26）神奈川県より編入の北多摩郡の一部 c . 1920年（大正 9）四谷 区に編入の内藤新宿町 d. 1950年（昭和25）埼玉県より編入 e. 1926 年

（大正15）埼玉県より編入 f. 1896年（明治24）東多摩郡と南豊島郡を合わ せて豊多摩郡となる（・印後の郡役所）

しただひとつ板橋区は分割して 2 つ分けて成立したものである。ての境界 はその後今日までに部分的または細部にわたっては何か所も修正されている。 一時大きな話題になった中央区, 千代田区の境界をはじめ, 大田区, 品川区の 
間など人家の密集している地域でも区境の変更が見られたし，小範囲の区界の 変更は他の区でもいくつか行なわれた。また，世田谷区の西北部や目黒区の南 部などで粗い地図を見ただけでもいかにも不自然に思われる部分がいくつか残 されている。さらに, 23区の成立当時とは違い, 各区でとの人口の粗密やその 配分にアンバランスが目立って来た。しかしいずれにしても区の再編や，区の 存立を根本的に考え直すというところまでにはいまだいってない。

昭和 22 年以来の東京 23 区の基盤は，䀡和 7 年の「大東京」成立時の 35 区であ (1943) る。乙の35区は，明治11年の郡区町村編成法による15区から成る旧市域と，昭 和 7 年に 5 郡 82 町を編入して成立した 20 区から成る新市域の 2 つの部分に分け られる。旧市域の15区の範囲は明治22年の特別市制を実施する時, 周辺部の区 界を変更し，かなり思い切った整理が行なわれた。干住，板橋など市街地が指 状に外へ延びている部分は切られて郡部に編大され，指の股にあたる部分は人 家はなくとも区域にくり入れられた。乙れは後にも述べるように意義の大きい ことであった。その後, 旧市域の境界は，海岸の埋立地の編入を除けば，大正 9 年, 四谷区に豊多摩郡内藤新宿町が編入されたてとが, 唯一といってよいく らいの大きいものである。昭和 7 年に新市域が編入されてからまもなく，足立 区と葛飾区との間の境界変更が行なわれたし，旧市域の神田区と日本橋区，下 谷区の間などでも一部に境界変更があった。しかし，旧市域はもちろん，新市 域の区でも，区の性格は併合した町村の性格をひきつぎながらも，増加する人 口や資力をもとに新たな特性をより濃く塗り固めて来ている。

数か町村の併合によって新区が生まれ，また 2 つ上の区の統合が行なわれ たばあい，まず問題になるのは区役所の位置である。ふつう人口も多く，財政 的にも豊かな町村役場の位置が新区の中心になるが，人口増加のはげしい周辺 部ではわりあい短かい期閆で人口重心が移動し，それにともなって区役所の位 置もまた周辺寄りに移動していく例が見られる。江示川区では，はじめ荒川放 水路を隔てて小松川町と松江町が区役所の位置を争った。結局都心寄りの小松 川町のほう亿落ちついたが，まもなく旧松江町の中心よりも周辺寄りに地を求 めて新区役所を新築するようになった。葛飾区でも最初は旧本田町の役場を区 役所としたが，数年後に現位置の本田立石町に新築し移動した。これに対し， 足立区はいぜんとして放水路の南の旧干住町の中心付近にあって区域の幾何学 的中心からはいちじるしく偏っている。板橋, 練馬もほぼ同型式である。てれ らは人口重心が南に偏っているととや, 交通機関との関係にもよるが, 周辺地 域の発展によって，いつまでもその地位を保てるかどうか疑わしい。旧目黒と 
旧碑食の 2 町を合わせてできた目黒区などは，いちように市街地がつづいてい て, 人口分布にも大差がないためか, 旧中心のほぼ中間に，はやくから新区役 所を設けている。昭和 22 年に, 王子, 滝野川を統合してできた北区でも同じよ うな関係になっている。杉並，中野，世田谷などは，昭和 7 年に区が成立した 当時，統合した町村のうち中心になった町村役場の位置，またはそれにきわめ て近い地点にそのまま区役所が安定しているが，てれらは今日でも区域の中心 的位置としていちじるしく外れていない例であろう。

旧市域内で統合した区ではよほど積極的な意図をもたないかざり，新位置に 新しい区役所を計画建設するととがむづかしい。新宿，江東，墨田の 3 区は， それぞれ昭和 22 年に，昭和 7 年当時の旧市域と新市域にまたがって統合された 新しい区である。乙のととはこの地域で最も市街地の発展がはやく，新市域と 旧市域との接合が円滑に進行していたてとを意味するが，てのうち，江東，墨 田の 2 区は，今日でもなお旧市域がわの旧深川，旧本所の区役所の位置にとど まっている。逆に新宿区は最もはやく他の区にさきがけ昭和 24 年に, 現歌舞伎 町の位置に新区役所を定めた。千代田区は長く旧神田区役所を利用していたの がようやく昭和30年に九段の濠端の，文京区も長く旧小石川区役所にとどまっ ていたのがやっと昭和 34 年に春日町前の, それぞれ新庁舎に移った。台東，中 央，港の三区はなおそれぞれ，旧下谷，旧京橋，旧芝の区役所を利用してい る。区役所のうちには, 位置はもとのままでも, 建物は大きくなり高層化して， 面目を一新しているものが多いが無方針に堅牢化して都市再開発の障害となる まえに，区の地位と大都市全体の中で占める区役所のイメージに合うよう，位 置そのものを検討しなおすととが必要であろう。

区域の母体である旧町村の沿革にさかのばるとき，当然触れねばならなくな るのは「郡」およびそれとの関係についてである。郡も明治11年の「郡区町村 編成法」によって行政区画になった。自治体としての郡は明治23年の郡制の公 布施行によってはじまったが, 最初の郡制の一日も施行されなかつた府県が 7 つもあり，明治37年に，はやくも郡制廃止の案が出されている。郡制の廃止が 決まったのは大正10年で, 大正12年に実施, 郡役所だけは大正15年まで存置し た。その後の郡はただ地域的呼称として慣用されているにすぎない。しかした とえゆるい結びつきであっても，数か町村をまとめた地域の呼称である郡の性 格をかつての地域的接合関係を理解する便利な素材として利用しないわけには いかない。大正14年の大阪市の第 2 次市域拡張も, 種々関係官庁の見解のくい ちがいがあった後, 結局, 郡を分断せず, 西成, 東成両郡の全域を編入するて 
とになったし，昭和 7 年の東京市の拡張も，すでに郡という法的存在はなくな っていても，結果として 5 つの郡境域の完全吸収になったわけである。4）この とき東京市に編入された南葛飾, 足立, 北豊島, 豊多摩, 萑原の旧郡役所の位 置は, それぞれ, 小松川, 千住, 板橋, 淀橋, 品川であった。さきに, 足立区 と板橋区役所が域の南縁に偏っていることに触れたが，それらは旧郡役所の 位置に区のも近接していて, その付近の吸引力の強い地域的伝統をひきつぐも のである。ての点は品川についても同様で, いまの品川区役所はその西となり にあった萑原郡役所の位置をうけついでいる。品川，千住，板橋とともに江戸 四宿の一つに数えられた内藤新宿も, 淀橋に移るまでの郡役所の所在地（はじ め南豊兒郡役所，のち東多摩郡との連合郡役所になる）で, 郡の中心としての 位置を守っていた。郡は，大都市内部でも地名などで，数区を管掌する公私の 機関の活動範囲をまとめて表わす地域的呼称として, なおかつての地域的接合 関係の名でりを伝えている。郡の範囲, 郡役所の位置は, そのてろの交通関 係，人口分布の重心などを象徽しているが，それから印象づけられる地域的パ タン, 地域的活動の濃淡，傾斜などが，なんらかの面で今日においても見えな い力として働いているととに留意したい。

\section{3. 境界の近代化とその改編}

区の境界は，どのようなものによるのが便利であり，またそれが合理的であ ろうか。大都市はすでに人家の密集している連続した地域であるが，てれを適 正な規模をもつ地域に分かつものが区であるが゙り，そのうちでも比較的分割 的要素として考元られやすい, 道路の幅広いもの, 大きな線路などによるのが まず妥当であろう。しかし流動性の強い大都市地域では, 川や道路のもつ意味 も変化して来てかんたんにてれらに頼るのがよいとはいい切れない。

川が埋立てられてビルが建てられると，その固定資産税収入などからすぐ問 題が起る。幅の狭い道路が広げられると, 境界として不自然であったものがそう でなくなるととがあるし，逆に小さい川が暗架となって地下に没し，上が道路 になると，てれを境界にするてとが不適当になりやすい。国鉄や私鉄の線路な ぞもいくつも踏切りがあってかんたんに横断できるばあいと，堤防のような高 架式で両側の地域が分離されているものとを同一視ずるわけにはいかない。高 架式でも線路の下が商店街になっているようなばあいは，地下鉄がもぐってい るのと同様で両側の地域を分離する意義もなくなる。自動車の往来のはげしい 道路は, 踏切りのある私鉄の線路よりも学童横断などのばあいに問題になり,区 


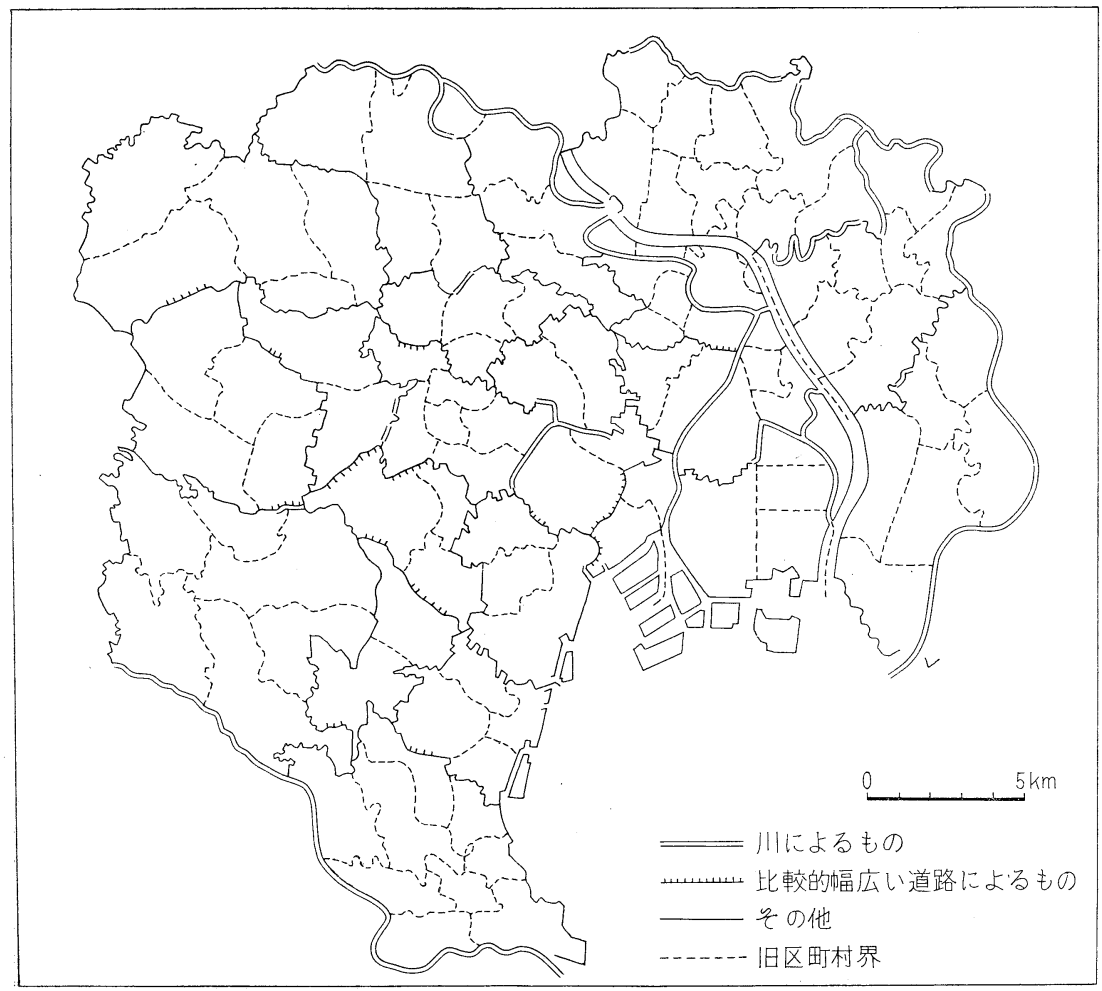

第3図東京23区の境界

はそのままでも学区だけは他の区の学区に入れようとする運動も起っている。 第 3 図は東京23区について，いちおう区の境界として明瞭で，現状では罗当 と思われる部分を記したものである。妥当子部分はほとんど川で，道路の場合 は3 車線級以上の幅広いものに限った。世田谷区と川崎市の境界は汇濫原の間 にかなり出入し,中の州を分離しているとてろがいく䇴所もあるが，いちおう多 摩川が境ということになっているため妥当な部分に入れてある。

狭い範囲の境界線の出入りは縮尺の大きい四によるほど目につきやすい。い つぱんに東京の区部ではこのような部分のなお残されている筬所が特に西部の 区域に多い。

川の多い東部の区域でもとれを有效に利用しているのは墨田区ぐらいであ る。 


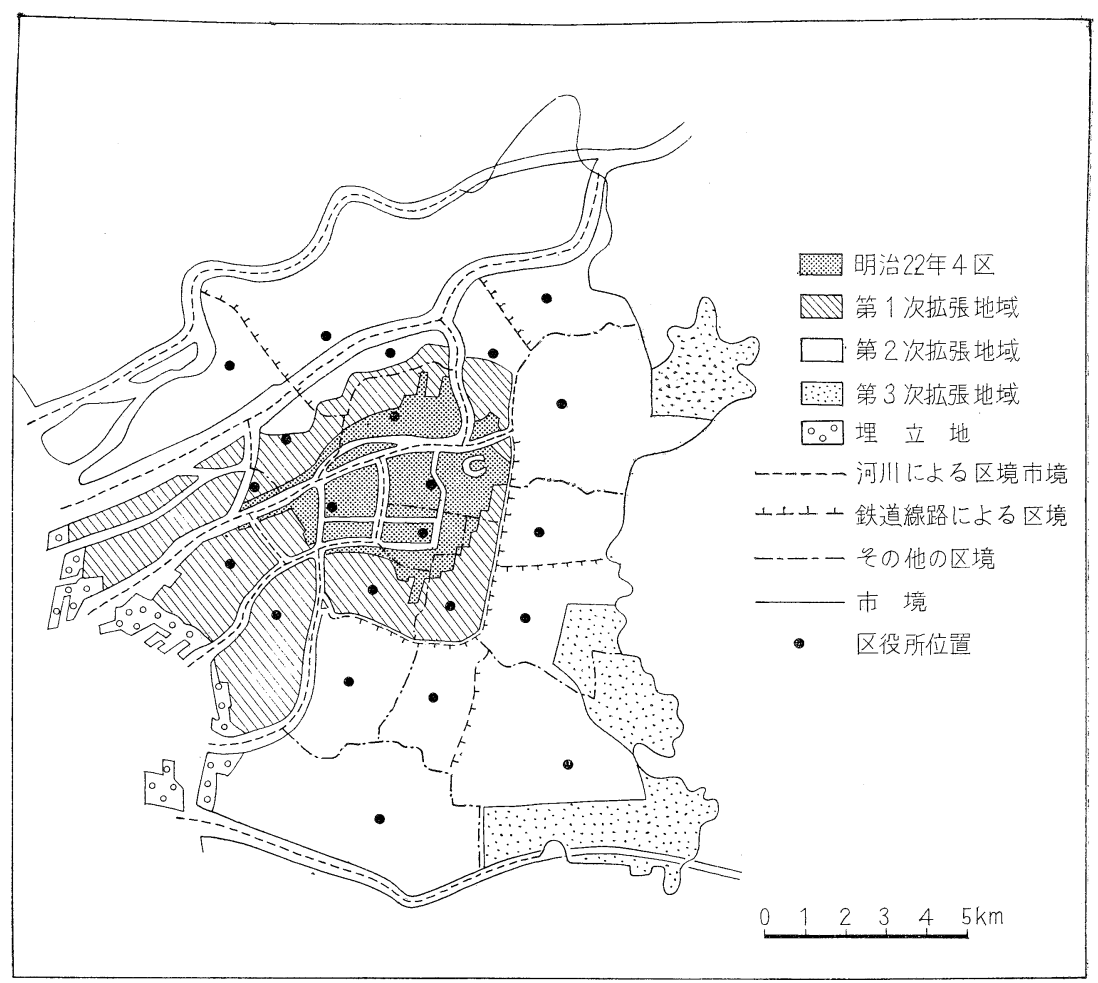

第 4 図 大阪市域の拡張（「大阪市制90年の步み」その他による）

墨田区では江東区の旧深川地域に接する部分を除けば，まず妥当な境界が印 されている。

東京で最も幅広い荒川放水路を区の境界にするのは墨田区を除けば，ほかに なく，江東区の下流の部分には見られるが，乙こは旧中川の川口と一致し，乙 れによった旧町村界を踏襲しているにすぎない。線路が境界になっているとて ろは一つも見られない。5～区の境界は旧町村の境界をうけつぎ鉄道線路のよう に後から設けられたものをこれにかえるにはよほどの積惯さが要るが東京では 明治22年に旧15区の周辺部を整理した以外，てうした意図が見られない。果し て，ぞの大都市でもそうなのであろうか。大阪と名古屋のばあいについて触れ てみよう。

大阪は明治30年, 大正14年, 昭和30年と 3 回にわたってほほ3 30 年おきに市域 を拡張した。このうち第 3 次拡張以外は規模が大きかった。第 1 次の拡張は28 


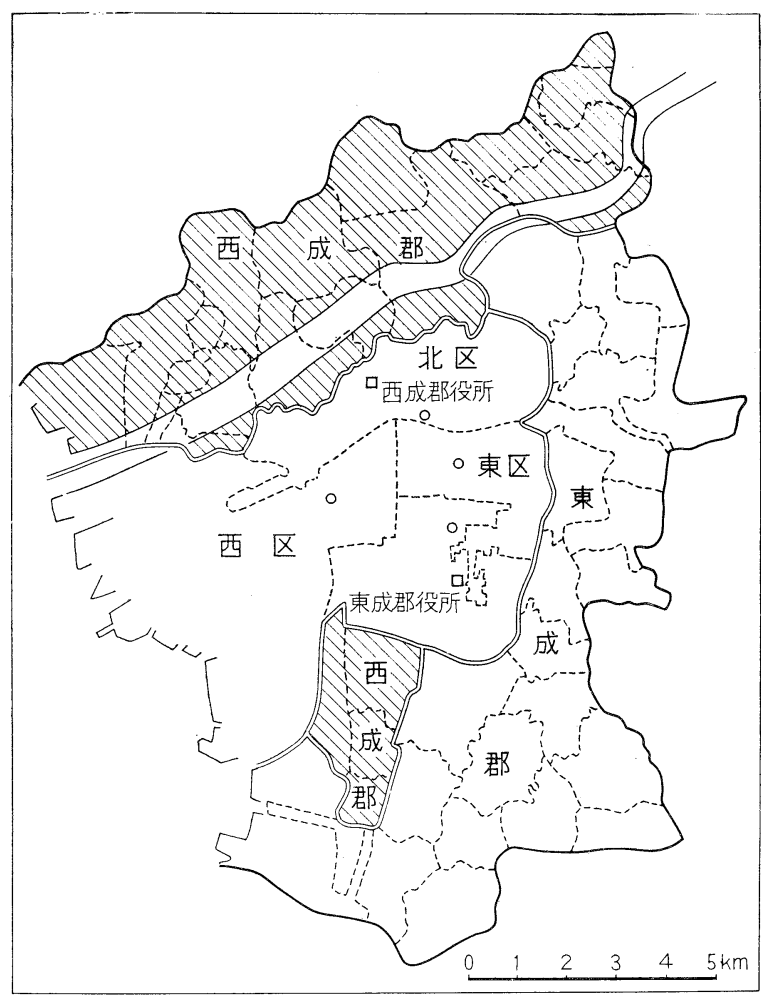

第 5 図 1925年 (大正14) 第 2 次市域拡張直前の大阪市 の郡区町村界（大阪市域拡張史〔1935年〕その他による）
か町村の全部または一 部を併合したものであ るが，市琙の決定は町 村界のみではなく，河 川，街道，鉄道線路な ぞによっている。特に 東南部の旧城東線，現 大阪環状線を新市域の 境界としたととは注目 される。この拡張の結 果，旧市琙で旧東京の 干住や板橋にあたる天 神橋筋（亀岡街道）日 本橋筋 (紀州街道) 安 治川沿いなどの市街䛧 の突出部は新市域の中 に埋没した。しかし新 市域はそのまま従来か らの4区のそれぞれに つけ加わっただけで， 根本的な区の改編は行 なわれなかつたため，

区の境界で出入のはげしい部分がかえって目立つてとになった。南区と東区の 東部における境界などがそれである。また郡の一部を編入したために，郡役所 が郡境の外に出て市内に位置し, 西成郡は南北に分離されるととになり, この 状態が第 2 次市域拡張時までつづいた。第 2 次の市域拡張は，西成，東成，両 郡の全域にあたる44か町村を編入したもので，昭和 7 年の大東京の成立よりは やくわが国最大の都市行政地域をつくるととになった。この時旧市域は 4 区を 増して 8 区となり，新市域の 5 区とともに13区にふえた。その後，昭和 7 年 に，大正区と坦区がそれぞれ港区と東成区から分離して計15区となったが，区 境の大部分はそのままで，いぜんとして不自然な部分が残されていた。てれに 根本的に手をつけたのは，昭和18年の22区制の実施時からである。区の自然の 境界となりやすい古くからの川や運河がかならずしもそうではなく，てのとき 


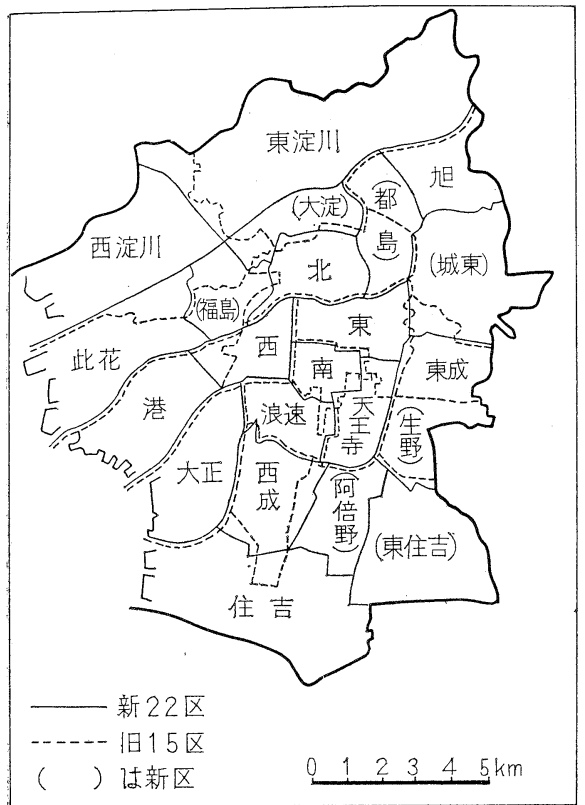

第6 図 1941年（昭和18） 区改編時 の大阪市（「大阪市制90年の步み その他による)

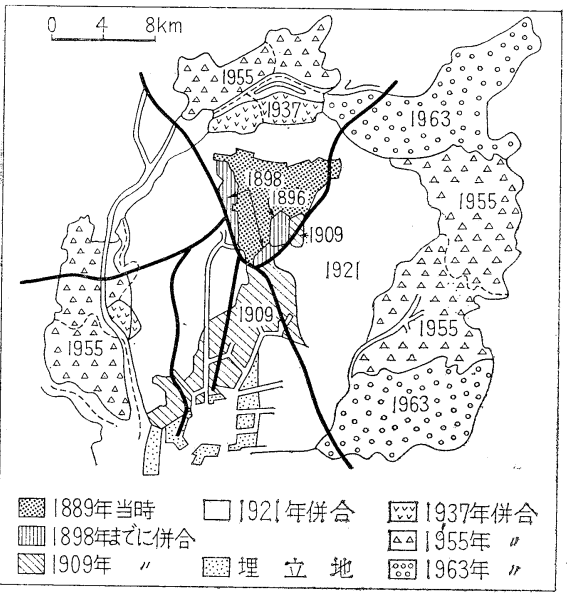

第 7 図名古屋市域の拡大

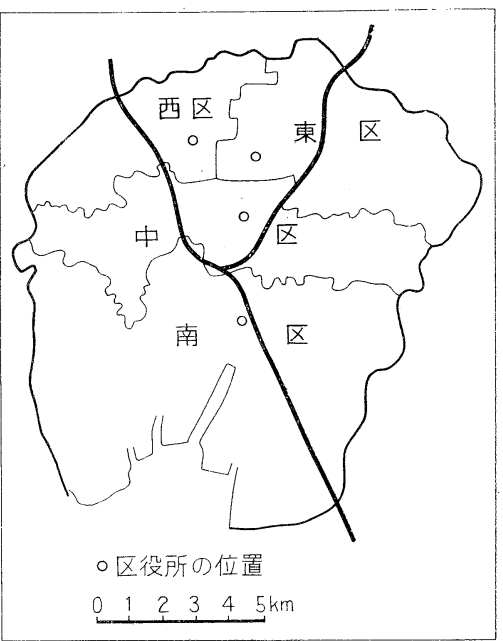

第 8 図 名古屋の旧 4 区 (1943 年まで)

になってようやく実現した部分の多 いととは第 5 図と第 6 図に見られた とおりである。下り東海道本線，城 東貨物線, 近鉄奈良線, 阪和線など を区境に採用したてとも北部で大正 14年当時の新市域と旧市域にまたが って区境が改編されたとととともに 画期的なものである。河川，鉄道以 外の区境もほとんど 3 車線級以上の 直線的な道路によっている。これら は東京のばあいといちじるしく異な る点であるが，不自然な境界といえ ば，東部の第 3 次合併によって市域 になった部分くらいである。ただ中 八部では, 直線的ではあるが東区と 献方博労町と順慶町通りの中間 
で，明治初年以来の境界線を保持しているのが注目される。東区と南区が，そ れぞれ人口と面積が現在では大阪で最小の区であるととは次の項で間題にする が，とこでも注意が要る。

名古屋は，明治40年に熱田を併合した翌年，東，西，南，中の 4 区をおいた。 大正 10 年の 16 力町村の併合の結果は 4 年後の大阪の第 2 次市域拡張範囲の 8 割 を越える面積になっていたが，新市域は旧 4 区に旧町村を単位に分割して併合 された。区の再編されたのは昭和12年の 3 か町村併合の年, 千種, 中村, 昭 和, 熱田, 中川, 港の 6 区を加えて10区になったときである。その後昭和19年 に, 中区, 東区, 昭和区, の一部を改編して栄, 北, 瑞穂の 3 区を独立させ, 13区となった。翌年栄区が中区に吸収されて12区に減った。てれに昭和38年， 守山市と鳴海町の編入によって生まれた守山区と緑区を加えて，今日の14区が 成っている。名古屋市の中心部における区域の大部分は昭和12年に改編された ものがつづいているわけである。てのとき区の境界を他の大都市に先んじてか なり思い切って部分的にしろ近代的なものにしたてとはその積極的意図をうか がえる点である。第 2 次世界大戦後, 戦災都市の復興と, 新しい都市計画で, 名古屋が他の大都市に比べてきわめて意欲的なてとはしばしば指摘されている が戦前からそれと間連深い実績がいくつも残されているととにも注意したい。

名古屋の中心部の古い市街地は, 明治年間に東海道線と中央線をいちおう境 界として市域に編入したが，細部ではかなり出入があった。てれを中心にする 改編された中区は, 東はほぼ中央線, 西は思い切って堀川で切られるととにな った。全部ではないが新しい西区，中 村区, 中川区, 熱田区の境界に下り東 海道線, 関西線, 東臨港線がとられた ことも大きな変化である。区として は，西区が区名はそのままでも，もと 区役所の位置が中区に編入されて, 相 対的に中心が西北に移動した。また， 南区は中心であった熱田が熱田区とし て独立し，新たに南に独立坞域を設け それぞれ新しい地域を指す区名に変つ た。直線的な境界の見られないのは中 央線以東の住宅地域で, 西部や南部に 比べてやや市街地の伸長の遅れた部分

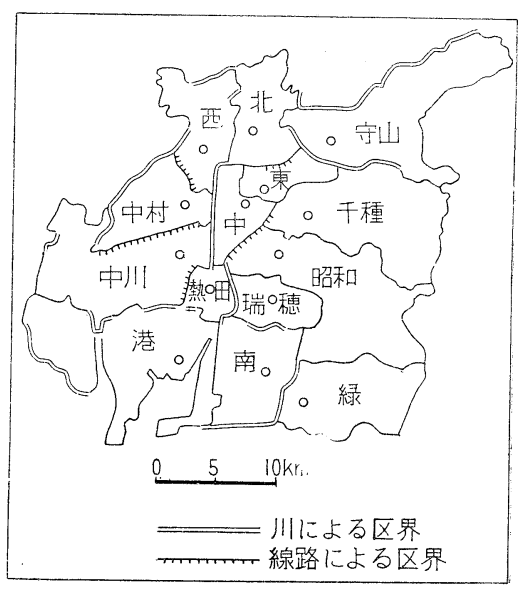

第 9 図 名古屋市の現14区の境界 
である。昭和区，瑞穂区などは区役所の位置が長く区域の西辺に偏り，戦後に ふってそれぞれ $2 \mathrm{~km}$ 近くも東に移動して現位置に落着いた。明治初年熱田に おかれた愛知郡の郡役所は, 熱田が名古屋に編入されてから, 東の旧御器所村 のもとの八高（現名大教養学部）の北，いまの向陽高校の西寄りに移転した。 その位置は，昭和，瑞穂両区役所のほぼ中間の西寄りにあたっている。この地 域は大正10年に市域になった部分で，郡役所廃止までとこから動かなかった。 郡役所の位置が市にあったものは大正15年に 547 中 107 あるが, 6) との大部分 汢市が生まれるより前にその位置にあったものにすぎない。市域の外にあった 郡役所の所在地が市域の拡大のためその部分だけ郡から切離して繰入れられた のは，前記の大阪のほか, 名古屋, 京都, 横浜のばあいに限られる。そのうち でも郡役所か郡の境域から押し出されて移動し，郡制の終りを迎える結果にな ったのは, 名古屋のほか, 後に述べる横浜のはじめ神奈川にあった椅樹郡役所 が，川崎に移った例があるくらいである。

\section{(注)}

1）郡区町村編成法第 4 条

2) 区の数は明治22年の市制実施直前に，37であった。東京の15, 京都の 2 , 大阪の 4, のほか, 横浜, 神戸, 名古屋, 長崎, 新潟, 堺, 函館, 仙台, 金沢, 岡山, 広島, 赤間関 (下関), 和歌山, 福岡, 熊本と, 札幌である。

3 ）明治 22 年法律 12 号第 6 条。

4）北多摩郡に属していた旧千歳，呫の二村は 4 年遅れて世田谷区に編入された。

5) 中央線が千代田区と新宿区，交京区の境界になっているように見えるがその北が わの外濠が境界である。

6）「郡制度に関する資料 昭和 31 年，自治庁」547 は郡役所の数で郡の数はこれより 約80多かった。 